\title{
Misguided and Misdiagnosed: The Failure of Decentralization Reforms in the DR Congo
}

\author{
Pierre Englebert and Emmanuel Kasongo Mungongo
}

\begin{abstract}
The DR Congo embarked upon decentralization reforms in 2006 to improve governance and accountability, undermine predation, corruption, and personal rule, bring government closer to the people, and promote local development. As of 2014, despite some regional variations, Congolese decentralization had instead increased the degree to which the state extracts the resources and incomes of its citizens. It had also fostered provincial centralization at the expense of local governments, produced largely unaccountable provinces governing with little transparency, and unleashed self-serving provincial elites. After providing original empirical evidence for these claims, this article suggests that decentralization was thwarted by the failure of formal reforms to affect informal ruling institutions and by an erroneous diagnosis of Congo's governance failures that singled out the abuse of elites without identifying the generalized nature of the instrumentalization of sovereignty by officeholders at all levels of the state. The article concludes by using Congo's experience to illustrate important flaws in decentralization reforms in Africa.
\end{abstract}

Résumé: La RD Congo a entrepris des réformes de décentralisation en 2006 pour améliorer la gouvernance et la responsabilisation, déstabiliser la prédation,

African Studies Review, Volume 59, Number 1 (April 2016), pp. 5-32

Pierre Englebert is the H. Russell Smith Professor of International Relations and a professor of African politics at Pomona College, where he also directs the African Politics Lab. His most recent books are Africa: Unity, Sovereignty and Sorrow (Lynne Rienner, 2009) and, with Kevin Dunn, Inside African Politics (Lynne Rienner, 2013). Most of his research focuses on the formation, reproduction, and decay of African states, with a particular focus on Central and West Francophone Africa. E-mail: penglebert@pomona.edu

Emmanuel Kasongo Mungongo is a professor and vice-dean in the Faculty of Social, Political and Administrative Sciences at the University of Kinshasa. His teaching and research focus on public administration and local governance, with particular attention to issues of local public finance. He has consulted for the World Bank and other donor agencies. E-mail: emakasongo@yahoo.fr 
la corruption et le pouvoir personnel, rapprocher le gouvernement du peuple, et promouvoir le développement local. Dès 2014, en dépit de certaines variations régionales, la décentralisation congolaise avait plutôt accru la mesure dans laquelle l'état prélève les ressources et les revenus de ses citoyens. Cette décentralisation avait également favorisé la centralisation provinciale au détriment des collectivités locales, produit des provinces très peu responsabilisées gouvernant avec peu de transparence, et avait déchaîné des élites provinciales principalement motivées par leur propre intérêt. Après avoir justifié ces revendications à l'appui de preuves empiriques originales, cet article suggère que la décentralisation a été entravée par les réformes formelles qui n’ont pas réussi à influencer les institutions dirigeantes informelles et par un diagnostic erroné des échecs de la gouvernance du Congo qui a distingué l'abus des élites sans identifier la nature généralisée de l'instrumentalisation de la souveraineté par les fonctionnaires à tous les niveaux de l'Etat. L'article conclut en utilisant l'expérience du Congo pour illustrer les failles importantes dans les réformes de décentralisation en Afrique.

Keywords: Democratic Republic of Congo; decentralization; provinces; reforms; taxation; predation; formal-informal dualism; instrumentalization of state authority

\section{Introduction}

It is now well established that the wave of decentralization reforms that has swept Africa since the 1990s has achieved at best partial gains in governance quality, administrative accountability, and development (Dickovick \& Riedl 2014; Lambright 2011). Like many African countries, the Democratic Republic of Congo (DRC) has embarked on decentralization reforms. And, as in most of them, implementation of these reforms has been only partial (Omasombo 2010; Gaynor 2014). Unlike the experience in the rest of Africa, however, and contrary to the expectations of the Congolese and aid donors alike, Congo's decentralization has produced a distinct worsening of the quality of its governance. Specifically, Congolese decentralization reforms have been accompanied by an increase in predatory extraction, provincial centralization of power, unbridled lack of accountability, and widespread rent seeking by provincial elites. ${ }^{1}$

What explains such an outcome? After providing original empirical evidence of these paradoxical effects of the reforms, we suggest that expectations of improved Congolese governance through decentralization were shattered because reforms failed to address two structural features of Congo's political system. First, they were misguided because they discounted the coexistence of formal and informal ruling institutions, and the immunity of the latter to decentralization's accountability and transparency mechanisms, allowing for the continuation of top-down extractive governance. Second, and perhaps more fundamentally, Congolese decentralization was predicated upon an erroneous diagnosis of Congo's previous governance failures, one that singled out the abuses of elites without identifying the 
generalized nature of the instrumentalization of sovereignty by officeholders at all levels of the state.

Although the perverse effects of Congo's decentralization might stand as outliers by African standards, they nonetheless illustrate important flaws in decentralization reforms in Africa. The preponderance of informal ruling mechanisms and networks may be higher in Congo than in many other African countries, but the formal-informal duality is nonetheless common across the continent (Englebert \& Dunn 2013). Indeed, Dickovick and Riedl's (2014) comparative survey of African decentralization highlights the degree to which several regimes use informal mechanisms of control to rein in decentralized entities. Congo probably takes this a step further and illustrates more vividly than other countries the limits of formal reforms in regimes that are only partly formal. In addition, Congo's paradox points to the weakness of the demand-driven governance model implicit in the decentralization agenda, which sees poor governance as proceeding from the inability of African citizens to hold their rulers accountable. The inefficient and at times predatory behavior of Congo's provincial authorities suggests that poor governance may also derive from organizational difficulties in producing the local institutional arrangements that could be conducive to the provision of public goods (Booth 2012).

\section{Decentralization's Promise}

For thirty-two years, the Congolese endured a dictatorship characterized by absolutism, thievery, impunity, and institutional dysfunction (Callaghy 1984; Schatzberg 1989; Vansina 1982; Young \& Turner 1985). Then, for almost another decade, Congo succumbed to chaos and violence (Prunier 2009; Stearns 2011). Having experienced this history of abuse and domination-and, to use a common expression in Congo, the "anti-values" of their leadership-many Congolese have long hoped that decentralization, if not federalism, could bring them a measure of relief. This was the preference they expressed at the 1991-92 National Sovereign Conference (CNS), at the 2001-3 Inter-Congolese Dialogue, and again during the 2003-6 Transition (Nzongola-Ntalaja 2002; Bouvier \& Bomboko 2003; de Villers 2009). And it was the system they adopted with the 2006 Constitution, which they approved in referendum by 84 percent.

The desire of many Congolese for decentralized governance is not new. The Round Table Conference negotiations for independence in 1960 agreed on a system with six provinces, each with its government and assembly (Ndaywel è Nziem 1998), a compromise between unitarists and federalists who included autonomy-seeking political elites from Bas-Congo and Katanga. As the country was wracked by conflict, the 1961 Antananarivo and Coquilhatville Conferences had also called for some degree of federalism. And the 1964 Constitution, approved by referendum, increased the number of provinces to twenty-one and gave them a large degree of autonomy in an attempt to reduce the colonial arbitrariness of the state and the sources 
of conflict. The Constitution did not get implemented, as Mobutu seized power the following year and launched the country on the path of hypercentralization under his personal authority. Yet he too came to see decentralization as a possible remedy to the mal zaïrois, as evident in the lukewarm reforms offered in this direction in 1982 which promulgated a limited degree of administrative decentralization in response to mounting political crisis. However, these also remained largely unimplemented (Batamba Balembu 2014).

The debates that took place during the CNS and the Transition illustrate the extent to which decentralization was expected to address the "injustice ..., impunity, nepotism, regionalism, tribalism, clanism and clientelism" which the Constitution's preamble blames for the "ruin of the country." CNS delegates were eager to undo Mobutu's "privatized" state and saw federalism as its antidote. It would correct the tendency of administrators accountable only to Kinshasa to behave locally as in "conquered territory" and would create "new responsible administrators more motivated and more dedicated to rigorous management." A central concern was to give people a voice by bringing them closer to the centers of decision. In this respect, delegates envisioned twenty-five provinces in which nobody would have to travel more than 300 kilometers to reach the provincial administration (Ndaywel è Nziem 1998:781-82). The same ambitions to create an "administration of proximity," reinforce democracy with greater citizen participation, reduce the abuses of central power, energize development efforts through a better knowledge of local realities, and promote a more equitable allocation of resources figured centrally in the negotiations of the 2003-6 Transition (Bouvier 2012:129). Given the reluctance of power incumbents and the fear of many Congolese that full-fledged federalism might be a prelude to the country's partition, far-reaching decentralization was adopted as a compromise in 2006.

The new constitution gave the country's eleven provinces ${ }^{2}$ (Bandundu, Bas-Congo, Equateur, Kasai-Occidental, Kasai-Oriental, Katanga, Kinshasa, Maniema, North Kivu, Orientale, and South Kivu) exclusive jurisdiction in some fields of public policy (mostly education, health, agriculture, and rural development) and shared authority with the central government in some others; provided for the election of provincial assemblies, which in turn elect governors; and allowed provinces to retain 40 percent of government revenue raised within their territories and to levy their own taxes. It also turned towns, communes, rural sectors, and chiefdoms into "Decentralized Territorial Entities" (ETDs) with their own elective local councils and executives and authority in matters such as markets, sewers, parking, and so on.

Congolese aspirations dovetailed with those of aid donors, who generally see decentralization as promoting better governance, greater accountability, and more direct representation, while fostering stability and development (Carothers \& de Gramont 2013; Dickovick \& Riedl 2014). They count on decentralization to reduce the propensity of African regimes 
to veer toward personal rule and hypercentralization, and to allow for greater grassroots participation and better service provision at the local level (Dickovick 2014; European Court of Auditors 2013). This convergence of viewpoints brought about a significant involvement of donors in Congo's reforms, particularly the African Development Bank, the European Union, the U.K. Department for International Development (DFID), the United Nations Development Programme (UNDP), and the World Bank, and led to some early achievements, such as the passing of two "organic" laws (laws that implement specific constitutional provisions) in 2008 providing for the autonomous administration of provinces and clarifying the status of ETDs. Donors pushed for a "minimum platform" of shared governance and public finance reforms in which decentralization was prominent, and have since worked directly with provinces and ETDs in a number of areas, including (1) providing technical and institutional support for provincial revenue collection; (2) developing accounting procedures; (3) supporting legal revisions for proper functioning of provincial institutions; (4) building capacity for human resources and financial services; and (5) supporting provincial planning and budgeting (Williams \& Ghonda 2012; World Bank 2013).

Yet despite widespread commitment from the Congolese and donors alike, Congo's decentralization has not unfolded as anticipated and has not come close to fulfilling the hopes of its promoters. To an extent, as with many other decentralization experiences in Africa, the reality of reforms has fallen well short of expectations. But this is only part of the problem. In Congo, despite significant variation across provinces, decentralization reforms have reproduced and spread the dysfunctions of the Congolese state rather than curing them. Among its failures, decentralization has (1) increased the degree to which the state extracts the resources and incomes of its citizens; (2) fostered provincial centralization at the expense of local governments; (3) produced largely unaccountable provinces governing with little transparency; and (4) served the material interests of provincial administrators instead of those of citizens. We turn to an analysis of these four failures in the next sections, after first reviewing the partial nature of Congo's decentralization reforms.

\section{The Problems and Failures of Decentralization}

\section{Partial Reform}

Only a minority of the reforms that Congolese and donors enthusiastically embraced in 2006 have been implemented. Elections for provincial assemblies were organized in 2006, and these assemblies in turn elected governors in 2007. Two organic laws were passed in 2008 on the self-administration of provinces and the functioning of ETDs, together with a law setting up a Conference of Governors. But little else followed, and the adopted legal reforms saw little implementation (see table 1). No further provincial 
Table 1. Status of Decentralization Reforms in the DRC (as of June 2015)

\begin{tabular}{ll}
\hline Reform & Status \\
\hline Self-administration of provinces and ETDs & Laws passed ('08), poorly implemented* \\
Conference of Governors & Law passed ('08), poorly implemented \\
Provincial elections & Once, in '07; not since \\
Financial transfers ("rétrocession") & Partial \\
New public finance law & Law passed ('11) \\
Public Investment Fund for Provinces** & No \\
Creation of new provinces (“découpage”) & Law promulgated March '15*** \\
ETD elections & No \\
Transfer of jurisdiction in decentralized areas & No \\
Transfer of personnel to provincial ministries & No \\
Separating decentralized \& deconcentrated & No \\
$\quad$ services & \\
Reform of public service & No \\
Transfer of assets ("patrimoine") to provinces & No \\
Transparency of provincial expenditure chains & No**** \\
\end{tabular}

\footnotetext{
* Undermined by 2011 constitutional reform which authorizes the president to remove provincial governors and appoint new ones.

** Caisse Nationale de Péréquation

*** Undermined by subsequent appointment of "special commissioners" by president, and suspension of provincial assemblies.

***** Aside from ex post audits by Cour des Comptes in 2013 for the 2011 accounts of seven provinces.
}

elections took place, and ETD elections have yet to happen. The national government by and large did not transfer jurisdiction to the provinces, nor did it reassign civil servants to provincial administrations in the areas decentralized by law.

Far from letting provinces retain 40 percent of the domestic revenue they generate, the central government has continued to collect all revenue and then retrocede a portion to the provinces, the actual amount of which hovered between 6 percent and 10 percent from 2007 to $2013 .{ }^{3}$ To some extent, the shortfall can be explained by the lack of transfer of personnel from the central administration to the provinces and the continued lack of effective jurisdiction of provinces in the areas decentralized by law. However, if one adds the salaries of (national) civil servants working in the ministries (whose responsibilities should eventually be decentralized) and the investments of the national government in the provinces, the total still falls below 30 percent.

The lack of government interest in decentralization is evident in budget figures. In 2013 the Ministry of Decentralization received only 11.7 percent of its budget, compared to an overall budget execution rate of 69 percent (not including aid-financed expenses), and the Comité Technique d'Appui à la Décentralisation (the Technical Support Committee for Decentralization, or CTAD) received a little over one-third of its budget. In contrast, the president's cabinet received 243 percent of its budget, the prime minister's 
cabinet received 227 percent, and the cabinet of the government spokesman 202 percent. $^{4}$

For sure, partial implementation is common to many types of policy reform across Africa. Nicolas van de Walle (2001) diagnosed this "partial reform syndrome" in the realm of structural adjustment programs in the 1980s and 1990s, and Matt Andrews (2013) showed that it is the default outcome of public-sector reform programs across low-income countries. Limited implementation is also the modal outcome for decentralization in low-income countries (Dickovick 2014; Dickovick \& Riedl 2014). The paradox of Congo's decentralization failure is more than a case of partial reform, however. As the next sections show, it is one of captured reform, in which those intended to implement the reforms locally hijack them and produce outcomes that at least in part reproduce the problems decentralization was intended to solve.

\section{Provincial Taxation and Rising Rates of Extraction}

Articles 50 and 51 of the Constitution confer taxation rights to provinces, including the levying of Common Interest Taxes (Taxes d'Intérêt Commun, or TIC) such as a vehicle registration tax, a business license fee, and taxation on the consumption of locally produced alcohol and tobacco, on the size of forestry and mining concessions, and on the artisanal extraction of precious metals, to be shared 60-40 percent with ETDs. Provinces can also create "province-specific" taxes on "local matters not already taxed by the central government" and collect "administrative revenues attached to the acts that fall under their jurisdiction."

Provinces have seized upon their new taxation rights with voracious appetite. In Bas-Congo, two 2007 edicts established seventy-four taxes for the province and fourteen for ETDs. The first included taxes on rental income, building permits, and the deliverance of market trader cards; it expanded the TIC consumption tax to cement, flour, and sugar; and it added fees for cutting trees and for the deliverance of certificates of noncontagion of human cadavers. The second edict taxed the loading and offloading of cargo in the port of Matadi, electronic funds wires, consumer goods produced in the province, imported vehicles, pollutioncausing activities, the sale of prepaid phone cards, and wood exports, among others. Bas-Congo also subsequently adopted tolls on national, provincial, and local roads, as well as taxes on school fees, the survey of real estate lots, the rental of electric poles (on which people post ads and banners), hunting permits, trash, water and electricity, the sale of charcoal and firewood, pest control, and on the exhumation of human cadavers (leading a provincial assemblyman to wonder, "Can we consider death as a source of revenue?"). 5

Because the central government has yet to transfer jurisdiction and staff to provinces in the policy areas decentralized by law, it is not uncommon for provinces to raise taxes or charge fees without delivering 
any of the services associated with them. Thus Bas-Congo has a tax on school fees but it was not, as of 2014, in charge of education in the province. It also has a tax for the collection and dumping of trash, but it did not collect trash or have a provincial dumping site at the time of our visit.

The province of Kinshasa embarked on a similar tax-expansion drive, spawning more than one hundred new taxes between 2008 and 2013. Like Bas-Congo, it broadened the consumption tax, added a "pollution tax" levied on the use of (ubiquitous) plastic bags (although there is no visible evidence that they get cleaned up more often now), and imposed a U.S.\$5 airport departure "statistical" tax, although air transport is not part of its jurisdiction and the national Régie des Voies Aériennes (Airway Board) collects air transport statistics and has its own departure tax. Kinshasa also applies taxes on notarized documents, real estate transactions, advertising, parking, and the organization of public events. According to an adviser to a Kinshasa provincial deputy, the province is also considering a tax on hygiene inspections ("you have no idea" how much could be made here, he said), parking, hotel rooms, casinos, reception halls, and funeral homes, the improved execution of real estate and vehicular taxes, and even a tax for entry into Kinshasa. In his words, "even if it comes down to mere crumbs, the [province] must have its share" (interview, Kinshasa, January 2014).

In Katanga, by far the richest province with about one-third of GDP, authorities rapidly sought to harness resources from the mining industry. Although provinces do not have direct jurisdiction over the mining sector, Katanga relies upon the use of "exceptional revenues," a new tax category that bypasses the limitations of the law. The two main taxes in this category, which make up two-thirds of provincial tax revenues, are a "tax for the rehabilitation of provincial infrastructure" and a tax charged to mining companies that export their copper and cobalt without first transforming them into cathodes in Katanga (Katanga Revenue Authority [DRKAT], interview, Lubumbashi, March 2013).

Despite their lesser degree of economic activity and weaker administrations, poorer provinces have also shown taxing enthusiasm. In KasaiOriental, as of mid-2012, twenty-five of the thirty edicts adopted by the provincial assembly since its installation dealt with the creation of new taxes. Among its province-specific taxes are a 1 percent tax on the value of diamonds that leave the province, as well as road and river-crossing tolls. For a while, it even had a tax on the drilling of wells (Minister of Economy and Finance Emmanuel Lukus, interview, Mbuji-Mayi, August 2012), even though only 43 percent of the province's residents have access to drinkable water (Bouvier 2012). Bandundu also has road tolls, and South Kivu charges a U.S.\$7 fee to those boarding the ferry to Goma in Bukavu. In 2010 Orientale province established a U.S.\$350 tax on any vehicle transporting imported petroleum in the province, and temporarily closed down and fined some gas stations that did not pay it.

Provincial tax proliferation brought about a pushback from the central government, which sought to circumscribe provincial innovations with 
a 2013 Law on Tax Nomenclature, which lists all legal provincial and local taxes. The nomenclature recognizes four provincial income taxes (impôts), 135 TIC taxes (many of which previously existed at the national level), and sixty-one province-specific taxes. Although the law fell short of capturing the full range of provincial fiscal innovations, it shows the deep reach of provinces into the daily lives and activities of the Congolese. Included in the law are taxes and duties on riding bicycles, making charcoal, having vagrant animals, cutting trees, destroying expired medicine, taking pictures of provincial sites, obtaining "verification certificates of aquarium fish" (arguably of limited relevance to the majority of Congolese), transferring "human cadavers from one province to another," and the issuance of "certificates of non-contagiousness of transported cadavers," suggesting the spread of Bas-Congo's innovations regarding taxing the dead. Provincespecific taxes also include several of the "new" taxes adopted by some provinces, such as the tax on the loading and offloading of cargo at ports.

Despite the government's efforts, anecdotal evidence suggests that the 2013 law has not fully reined in the fiscal ardors of provinces. According to a staff member of the Comité d'Orientation de la Réforme des Finances Publiques (Steering Committee for the Reform of Public Finance, or COREF), the provincial "tax grab" has continued (interview, Kinshasa, January 2014). Kinshasa's airport tax, for example, was adopted after the new law was passed; so was a new Bas-Congo U.S.\$100 tax on imported vehicles, as well as South Kivu's tax for traveling on Lake Kivu. A Congolese consultant for the World Bank euphemistically hinted that "provinces have to be assisted in gaining ownership of the nomenclature" (interview, Kinshasa, January 2014). And ETDs too have developed their own new taxes, the multiplicity of which partly reflects the paltry revenues that many of them provide. The 2013 law identifies fifty-three town-specific taxes, forty-eight municipal taxes, and thirteen chiefdom or sector taxes.

Altogether, Congolese decentralization has unambiguously increased the number of existing taxes and fees faced by citizens. The 2013 law lists 314 combined provincial and ETD taxes. While this figure is similar to the three hundred local taxes that Markus Kostner identified as of 1997, it does not include several taxes that provinces still collect or have since imposed, and it is much higher than the number of such taxes under Laurent-Désiré Kabila, who had reduced them to sixty-two by 1998 . Hence, the number of taxes increased five-fold from 1998 to 2013.

Several provinces lack the capacity to collect many of the new taxes, some of which yield insignificant amounts. Nevertheless, all provinces have shown an unambiguous rise in revenue, aided by the establishment of tax authorities since 2007. Triangulating data from provincial tax agencies, audits by the Cour des Comptes (Court of Audit), the Reddition des Comptes (Accounts Rendering) division in the Ministry of Finance, and donor agencies working with provinces, and from execution figures from the Ministry of Budget, we compiled estimates of provincial tax revenues, which show a steady rise across all provinces (see table 2). By 2009 all 
Table 2. Estimates of Provincial Tax Revenues (in U.S.\$ million)

\begin{tabular}{lllrrrrrr}
\hline & & & & & & & \multicolumn{2}{c}{$\begin{array}{c}\text { Contribution to } \\
\text { National Revenue* }\end{array}$} \\
\hline Bandundu & 0 & 0 & 0.5 & 0.9 & 0.8 & 2.2 & 3.6 & 1.9 \\
Bas-Congo & 1.0 & 1.8 & 3.4 & 6.9 & 8.6 & 18.1 & 20.9 & 656.9 \\
Equateur & 0 & 0 & 3.2 & 3.6 & 4.0 & 4.5 & 5.0 & 7.7 \\
Kasai Occidental & 0 & 0 & 0.7 & 0.8 & 1.2 & 2.8 & 2.2 & 8.9 \\
Kasai Oriental & 0 & 0 & 1.5 & 1.8 & 2.2 & 4.3 & 5.0 & 9.7 \\
Katanga & 0 & 0 & 45.1 & 92.1 & 154.6 & 284.5 & 300.0 & 811.5 \\
Kinshasa & 0 & 0 & 22.3 & 24.1 & 37.0 & 49.4 & 54.4 & $2,133.1$ \\
Maniema & 0 & 0 & 0.4 & 3.1 & 3.0 & 3.0 & 3.0 & 2.7 \\
North Kivu & 0 & 0 & 5.2 & 7.1 & 6.0 & 6.1 & 6.8 & 115.9 \\
Orientale & 0 & 0 & 1.7 & 11.9 & 3.0 & 3.8 & 4.0 & 38.6 \\
South Kivu & 0 & 0 & 3.7 & 7.4 & 4.2 & 5.4 & 6.0 & 77.3 \\
Total & 1.0 & 1.8 & 87.6 & 159.6 & 224.4 & 384.1 & 410.9 & \\
(share of top 3) & $100 \%$ & $100 \%$ & $81 \%$ & $77 \%$ & $89 \%$ & $92 \%$ & $91 \%$ & \\
& & & & & & & &
\end{tabular}

In \% of Retrocession Payments (Financial Transfers Only)

\begin{tabular}{lclrrrrr}
\hline & $\mathbf{2 0 0 7}$ & $\mathbf{2 0 0 8}$ & $\mathbf{2 0 0 9}$ & $\mathbf{2 0 1 0}$ & $\mathbf{2 0 1 1}$ & $\mathbf{2 0 1 2}$ & $\mathbf{2 0 1 3}$ \\
\hline Bandundu & 0 & 0 & 4 & 11 & 6 & 18 & 30 \\
Bas-Congo & 13 & 8 & 20 & 49 & 42 & 99 & 103 \\
Equateur & 0 & 0 & 20 & 30 & 21 & 22 & 28 \\
Kasai Occidental & 0 & 0 & 6 & 8 & 10 & 25 & 18 \\
Kasai Oriental & 0 & 0 & 13 & 19 & 16 & 30 & 32 \\
Katanga & 0 & 0 & 189 & 370 & 479 & 647 & 880 \\
Kinshasa & 0 & 0 & 164 & 65 & 187 & 190 & 303 \\
Maniema & 0 & 0 & 6 & 53 & 26 & 27 & 26 \\
North Kivu & 0 & 0 & 55 & 84 & 49 & 41 & 55 \\
Orientale & 0 & 0 & 9 & 80 & 15 & 19 & 22 \\
South Kivu & 0 & 0 & 55 & 85 & 30 & 40 & 42 \\
& & & & & & & \\
\hline
\end{tabular}

Note: Estimates in italics.

* Provincial contribution to national revenue, based on 2010 estimated shares (Bouvier 2012:210) and 2013 total national revenue.

Sources: Ministère des Finances, Service de Reddition des Comptes; Ministère du Budget; Cour des Comptes; World Bank PRCG; UNDP; African Development Bank; Provincial governments of Katanga, Kinshasa, and North Kivu. Raw data available upon request.

provinces were beginning to accrue income. By 2013 total provincial tax income reached more than U.S. $\$ 400$ million, an increase of 369 percent. Over the same period, central government revenue grew by 123 percent. ${ }^{6}$

As table 2 indicates, there are large variations in the capacity of provinces to raise revenue, with three provinces (Bas-Congo, Katanga, and Kinshasa) accounting for more than 90 percent of the total. With some U.S.\$300 million in 2013, Katanga dwarfs all others. Kinshasa and BasCongo round up the top three with, respectively, U.S.\$54 million and 
U.S.\$21 million. Other provinces are far behind. These variations largely correspond to provincial wealth, as the top three provinces are also the source of 93 percent of central government revenue (see right-hand column in top half of table 2). They also reflect differential extractive capacity, partly a function of the ease of extraction. All provinces accrue most of their resources from a few localized and easy-to-administer items, like the consumption tax, road tolls, or mining-derived taxes. Provinces that rely on a few large payers (e.g., mining companies for Katanga, or the Matadi port for Bas-Congo) tend to do better.

While the tax revenues of some provinces may appear negligible, they need to be compared with what these provinces contribute to central government revenue. Bandundu and Maniema, for example, both raise more provincially than nationally (although Maniema's figures after 2010 are extrapolations). Figures are less comparable for Bas-Congo, the two Kivus, and Orientale because they contribute national revenue through custom duties collected on their international borders. Similarly, Kinshasa's revenue looks diminutive compared to its contribution to national revenue because many transactions are attributed geographically to Kinshasa although they originate elsewhere (e.g., the export of diamonds). For other provinces, tax revenues range from one-quarter to two-thirds of locally generated national revenue, suggesting the general significance of provincial taxation despite variations.

The bottom half of table 2 expresses provincial tax revenue in percentage of financial retrocession transfers from the central government. It shows that the richer provinces make more on their own than what they receive in retrocession. For Katanga, it was almost nine times more in 2013; for Kinshasa it was three times more; and Bas-Congo made about as much as it received. Other provinces remained below 100 percent, but the ratio appears to be rising everywhere (the higher figures for 2010 derive from a drop in retrocession that year).

Increased provincial taxation has likely resulted in the Congolese seeing more of their income taxed than they used to. Provincial taxation represents a growing proportion of total domestic government revenue (from $0.12 \%$ in 2007 to $10.63 \%$ in 2013) despite the rapid growth rate of the latter (see table 3). Thus provincial extraction has been growing faster than national taxation, although the overall effect is modest at 13 percent of GDP and concentrated in the three usual provinces.

However, national revenue in percent of GDP can be misleading to the extent that the government exempts many mining companies from taxes. The mining sector, particularly copper and cobalt, which had an output estimated at U.S.\$10.2 billion in 2013, produced only U.S. $\$ 0.5$ billion in national tax revenue that year (Englebert 2014), which represents about 9 percent of central government revenue. In other words, about one-third of the country's economic activity (the mining sector) generates 9 percent of government revenue, while the other two-thirds generate the remaining 91 percent. In this perspective, government and provincial revenue 
Table 3. Estimates of Tax Burden (in U.S.\$ million)

\begin{tabular}{|c|c|c|c|c|c|c|c|}
\hline & 2007 & 2008 & 2009 & 2010 & 2011 & 2012 & 2013 \\
\hline $\begin{array}{l}\text { National Budget Domestic } \\
\text { Revenue }(\$ \mathrm{~m})\end{array}$ & 826 & 1,312 & 1,735 & 2,437 & 2,993 & 3,672 & 3,864 \\
\hline Total Provincial Own Revenue $(\$ \mathrm{~m})$ & 1 & 2 & 88 & 160 & 224 & 384 & 411 \\
\hline Total Own Revenue (\$m) & 827 & 1,314 & 1,822 & 2,597 & 3,218 & 4,056 & 4,275 \\
\hline Total Own Revenue (\% GDP) & 5.1 & 6.8 & 9.9 & 12.0 & 12.5 & 13.8 & 13.1 \\
\hline Provincial Revenue ( $\%$ of National) & 0.1 & 0.1 & 5.1 & 6.6 & 7.5 & 10.5 & 10.6 \\
\hline Provincial Revenue (\% GDP) & & & 0.5 & 0.7 & 0.9 & 1.3 & 1.3 \\
\hline \multicolumn{8}{|c|}{ Using an estimated rate of revenue leakage of $2 / 3$ : } \\
\hline $\begin{array}{l}\text { Extraction through National } \\
\text { Taxation }(\$ \mathrm{~m})\end{array}$ & 2,478 & 3,935 & 5,204 & 7,310 & 8,980 & 11,016 & 11,592 \\
\hline $\begin{array}{l}\text { Extraction through Provincial } \\
\text { Taxation }(\$ \mathrm{~m})\end{array}$ & 3 & 5 & 262 & 479 & 673 & 1,152 & 1,233 \\
\hline $\begin{array}{l}\text { Provincial and National } \\
\text { Extraction }(\$ \mathrm{~m})\end{array}$ & 2,481 & 3,941 & 5,467 & 7,789 & 9,654 & 12,169 & 12,826 \\
\hline Total Extraction (\% GDP) & 15 & 21 & 30 & 36 & 37 & 42 & 39 \\
\hline Provincial Extraction (\% GDP) & & & 1.4 & 2.2 & 2.6 & 3.9 & 3.8 \\
\hline
\end{tabular}

Note: exchange rate U.S.\$1=FC920. Sources: See Table 2.

combined represent about 17.3 percent of nonmining economic activity. ${ }^{7}$ Provincial revenues amount to almost 2 percent of this revised GDP.

Moreover, the relationship between government revenue and the extraction performed by government agents (legally or not) is tenuous. In 2007 A. Batamba Balembu estimated the loss from leakages in tax collection at 55 percent of potential budget revenue (cited in Tedika 2012). The Extractive Industries Transparency Initiative (EITI), an international organization that monitors transparency in the management of natural resources, assessed total payments by mining companies to state agencies in 2011 at 0.95 billion, while total government receipts did not exceed 0.57 billion, leaving the use of 0.38 billion, or 40 percent, unaccounted for (EITI 2013). A 2013 study of Kinshasa's central market showed that of U.S.\$1.5 million taxes and fees collected from market traders, only U.S.\$280,000 accrued to the Treasury, amounting to an 81 percent rate of revenue leakage (ODEP 2013). And a 2014 survey of Kinshasa traffic police calculated a rate of accrual to official accounts over expected payments of traffic citations of about 4 percent. The same study assessed traffic police's "informal" monthly income at U.S.\$350 (U.S.\$500 for those on motorbikes) compared to official wages of U.S.\$75 (Malukisa 2014).

These findings suggest that official tax revenues represent between 4 percent and 60 percent of actual "tax" payments. The high visibility of the mining industry, in which donor-sponsored initiatives force greater transparency, probably accounts for its greater rates of compliance. Decentralized actors operate with much less oversight, and their rates may be in the lower 
part of the range. Based on the midpoint of these studies, one can estimate that official revenue execution figures may represent about one-third of actual payments. In that case, the overall rate of extraction by state agents is about 40 percent of GDP, while the provincial rate of extraction is about 4 percent of GDP (see bottom half of table 3 ). Moreover, if we focus only on our estimate of the nonmining share of GDP (about 2/3) and of its contribution to taxes (about 90\%), the national rate of extraction would exceed 50 percent while the provincial rate would be about 5 percent. At any rate, these figures suggest a rapidly rising fiscal burden for Congolese citizens.

Although these are estimates, the possibility that the Congolese face a real tax burden of about 40-50 percent of income does not seem unreasonable given anecdotal observations in the field. Our findings also square with those of a Congolese NGO, which estimated that the tax burden of traders in Kinshasa's central market amounted to at least U.S.\$150 per year, or about half the country's per capita income (ODEP 2013). Moreover, our figures do not take into account other fees and duties that many Congolese must pay, such as school fees or payment for the delivery of many vital documents such as birth and death certificates.

To sum up, provincial taxation adds up to 10 percent to the overall tax burden (and up to 5\% of GDP), and it is rising. Given their combined extraction of rent and relative lack of public good provision (on which more below), provinces resemble predatory states as much if not more than national authorities. As such, decentralization, by multiplying the number of agents with legal or plausibly legal authority to extract resources and the number of taxes in their arsenal, appears to have heightened the predatory nature of the state. In the words of a Kasai-Oriental Catholic nun, "people here have become slaves to taxes" (interview, Mbuji-Mayi, August 2012).

\section{Provincial Centralization}

In addition to increasing the rate of revenue extraction, decentralization reforms, paradoxically, have produced a pattern of centralization at the provincial level. Invoking their lack of retrocession from the central government and the administrative inability of ETDs to manage money, provinces typically fail to redistribute to ETDs the legally required 40 percent of what they receive. In 2012, for example, they transferred an average of 3 percentfrom 0 percent in South Kivu to 6.8 percent in Katanga (see table 4).

Not only do provinces not allocate significant resources to ETDs, they also tend to appropriate some of the latter's resources. TIC taxes, which must be shared 60-40 percent between provinces and ETDs, are often collected directly by provinces and then "retroceded" to ETDs in smaller proportions, if at all. In Kinshasa we obtained a copy of a 2010 letter sent by the province to businesses informing them not to pay the business license fee to ETDs. In Bas-Congo the tax was collected by the province in 2011 and retroceded by no more than 10 percent to ETDs (interview, territorial administrator, Mbanza-Ngungu, May 2011). As the provinces appropriate 
Table 4. "Retrocession" from Provinces to ETDs in \% of Retrocession Received by Provinces (constitutional requirement: 40\%)

\begin{tabular}{lc}
\hline & $\mathbf{2 0 1 2}$ \\
\hline Bandundu & $4.8^{*}$ \\
Bas-Congo & 4.1 \\
Equateur &.. \\
Kasai Occidental & 1.2 \\
Kasai Oriental &.. \\
Katanga & 6.8 \\
Kinshasa & 2.2 \\
Maniema & $3.8^{*}$ \\
North Kivu & $2.3^{*}$ \\
Orientale & 2.5 \\
South Kivu & 0.0 \\
Average & $\mathbf{3 . 1}$ \\
\end{tabular}

Sources: Cour des Comptes 2013a-f for 2012; Journal Officiel ODEP 2011.

* 2010 (most recent available estimate)

taxes designated by the law for ETDs, the ETDs are left with minimal or hard-to-collect tax revenues, which yield at best a few hundred dollars a day per commune (Englebert \& Kasongo 2014). As a result, their budgets are both minuscule and unpredictable, making local governance more hypothetical than real. Their main sources of revenue are daily taxes on market stalls (U.S.\$.10 to U.S.\$.20 per stall), fees for documents like death certificates, and weddings. In Equateur, ETDs tax artisanal miners, food items, canoes, bicycles, homemade alcohol, shop rentals, marriage and birth certificates, palm oil, river crossings, and charcoal (Atos 2014). This imbalance between the provinces and the ETDs undermines the foundations of decentralization, relocating authority and resources to provincial capitals in a process that Kasongo (2014) has labeled "provincial gangsterism."

\section{Top-Down Unaccountability and Lack of Transparency}

Part of this "gangsterism" is due to the lack of transparency in the provincial tax collection process. While provincial capacity for revenue collection has risen, "attempts to promote transparency and accountability [in provinces] encounter many more difficulties" (aid donor e-mail to authors, April 2014). The resulting performance of provinces hardly corresponds to the expected improvements in governance.

Provinces do not always adopt budgets. Equateur went without one from 2010 to 2014 (Atos 2014), and Bandudu did not have one for 2012. Even when budgets are adopted, they tend to differ greatly from actual revenue and spending. In Bas-Congo, the 2012 budget indicated U.S.\$20 million for equipment and U.S.\$58 million for construction and rehabilitation, but the actual expenditures on these two items were, respectively, U.S.\$4.3 million 
and U.S.\$2.4 million. In Kasai-Occidental, the 2012 capital budget execution rate was 7.2 percent. In Kinshasa, nine out of seventy-two equipment projects, thirty-nine out of 189 construction projects, and forty-eight out of 261 investment projects were implemented. In Orientale, 5 percent of budget spent on capital (which was only $3 \%$ of forecast public investment) was allocated to the partial implementation of twenty out of seventy planned projects. A project for the provision of school benches, blackboards, and lockers had an execution rate of 0.27 percent; hydraulic works and wells in villages had a rate of 0.34 percent; and power line repair had a rate of 1.59 percent. In South Kivu capital spending amounted to 6 percent of forecast (see Cour des Comptes $2013 \mathrm{a}-\mathrm{g}$ ).

Provinces also seem to escape most checks and balances in terms of how they spend their revenue. For 2009-10, the Cour des Comptes noted "numerous anomalies" and "unjustified expenses" in Bandundu, where 90 percent of functioning costs go to the governor's office and "irregular financial advantages" are granted to members of the provincial assembly, while provincial expenses face "recurrent absence of receipts" and public investments lack contracts and evidence of completion. For Bas-Congo the report noted "unjustified expenses," "frequent use of emergency procedures, and "poor accounting." In Equateur it noted "bad accounting," weak tracability of expenses, and weak execution of projects. And in KasaiOccidental the problem was "bad accounting," with lack of evidence of materiality of public contracts and nonimplementation of projects because funds were diverted into raises for provincial assembly members. In KasaiOriental most data was not made available. In Katanga the court noted a large number of direct payments to provincial ministers and other members of the provincial administration. In Kinshasa numerous "[out-of-budget] emergency spending procedures" were implemented, with a "total absence of receipts" in public investments and "disbursements without justifications." In Maniema auditors found "numerous expenses without justification." North Kivu displayed a "lack of orthodoxy in budget" and "bad accounting." In Orientale the court could find "no up-to-date accounting" but identified "numerous payments without justification," the "frequent use of emergency procedures," and the approptiation of "functioning costs" as extra salary by members of the provincial assembly. South Kivu abused exceptional procedures and did not provide justification and receipts for payments (see Journal Officiel (2011:31-177, passim).

In Equateur, Governor Jean-Claude Baende (2009-13) was accused of embezzlement of retrocession funds and of turning the provincial tax authority into his own "slush fund." A consultant's report noted that he was accused of "routine financial payments to [provincial] deputies in exchange for their support." Many of these deputies "do not speak French and have never taken the floor. . . . Being at the [Provincial Assembly] is primarily an opportunity to gain access to resources through posing the threat of a dismissal vote" (Atos 2014:15,19). Rumors that the votes of provincial deputies are for sale have been circulating in some other provinces as well since the 
2007 election of governors yielded outcomes that did not match the distribution of political parties in the assemblies of Bas-Congo (de Villers 2009).

Donors are aware of these weaknesses and have sought to boost accountability by establishing computerized expenditure chains and securitized purchase titles to track the use of provincial funds. Yet as of early 2015 these chains were not effective in any province. The resulting situation is one of imbalance between rising provincial extractive capacity and a high degree of provincial spending unaccountability. Paradoxically, provinces are significantly behind the still weak but improving standards in budgetary transparency at the national level, with the result that decentralization may well have reduced overall levels of governance quality. ${ }^{8}$

\section{Self-Serving Administrations}

Most provinces also appear largely focused on looking after the interests of their administrators. They allocate the majority of their resources to salaries and functioning costs, with most of it going to governors, their cabinets, and provincial deputies. (The salaries of civil servants working in the provinces are still paid by the central government.)

The most recent audits of the Cour des Comptes (2013a-g), for fiscal year 2012, reveal the extent of this self-focus. ${ }^{9}$ In Bandundu, 100 percent of personnel expenses went to the governor's cabinet. All of the U.S.\$18 million received by Bas-Congo in retrocession went to the functioning costs of the provincial cabinet and assembly; 73 percent of the province's current expenditure (which totaled about U.S.\$25 million in 2012) went to the cabinet of the governor and another 22 percent to the Ministry of Economy, Finances, and Commerce. In contrast, the Bas-Congo provincial Commission for Investments and Development (the Commission Provinciale des Investissements et du Développement du Bas-Congo, or COPIDE) received 0.02 percent (less than U.S. $\$ 5,000)$. Similarly, fertilizer allocations for the provincial Ministry of Agriculture were spent at about 16 percent of budget, while the communication budget of the governor was overspent at 1,253 percent and his publicity budget was overspent at 3,119 percent. These numbers support Gaynor's (2014:9-10) observations on the "lack of responsiveness of provincial authorities to local people's priorities" and the perception that "provincial authorities care only for their own interests." In Kinshasa, about 80 percent of current expenditure went to the governor's cabinet and to the Ministries of Finance and Economy, and Budget and Plan. In Orientale, 84 percent went to the governor's cabinet and the rest to the provincial assembly. In South Kivu in 2012 current expenditures were more than 20 times greater than total capital spending.

Without a doubt, decentralization has increased the number of claimants of state resources. We estimate that the eleven governors, eleven deputy governors, 110 provincial ministers, eleven speakers, and eleven deputy-speakers of provincial assemblies, along with 690 provincial deputies, 
generated a total annual provincial wage bill of up to U.S. $\$ 45$ million in 2009 , or 51 percent of provincial tax revenue that year-and this estimate does not include other positions that are funded by provincial budgets such as chiefs and deputy chiefs of staff, executive and deputy executive secretaries, advisers, "coordinators of studies," private secretaries, researchers, special envoys, assistants, provincial inspectors, rapporteurs, deputy rapporteurs, and clerks (Bouvier 2012). Some governors made as much as U.S.\$15,000 per month, or 455 times Congo's per capita income (see table 5).

These observations are not meant to imply that provincial authorities are only focused on spending resources on themselves and do not do the work of governing or making public investments. Bas-Congo allocated U.S.\$6.7 million to equipment and construction in 2012, some 40 percent of which went to the rehabilitation of provincial buildings. In KasaiOccidental, U.S.\$1.2 million (out of total revenue estimated at U.S.\$12.5 million) went to school and morgue constructions, ferry maintenance, anti-erosion work, roadwork, bridge and school rehabilitation, and acquisition of farmland. In Kinshasa the ratio of current to capital expenditure was about 50:50, with about 80 percent of the capital expenditure going to infrastructure work and a little under 10 percent to water provision. In Katanga some U.S.\$120 million (out of a budget of about U.S.\$340 million) went to equipment and construction, including about U.S. $\$ 90$ million for the rehabilitation and repair of roads, trails, the railroad, bridges, ports, and airports. In all the provinces we visited, we also observed that provincial authorities contributed, with national police and military forces, to the enforcement of security (Cour des Comptes $2013 \mathrm{a}-\mathrm{g}$ ).

Nevertheless, it is generally the case that provincial administrations do relatively little beyond taking care of themselves. To some extent, this

Table 5. Monthly Salaries and Bonuses of Provincial Personnel, 2009 (U.S.\$)

\begin{tabular}{|c|c|c|c|c|c|}
\hline & \multicolumn{3}{|l|}{ Executive } & \multicolumn{2}{|l|}{ Assembly } \\
\hline & Governor & Deputy-Governor & Ministers & Speaker & Deputy \\
\hline Bandundu & 12,219 & N.A. & 7,005 & N.A. & N.A. \\
\hline Bas-Congo & 10,786 & 7,939 & 4,387 & 9,002 & 5,435 \\
\hline Equateur & 8,474 & 6,459 & 3,913 & 10,000 & 7,000 \\
\hline KasaiOccidental & 5,837 & 4,652 & 2,989 & 4,891 & 2,554 \\
\hline Kasai Oriental & 3,696 & 2,893 & 1,394 & N.A. & N.A. \\
\hline Katanga & N.A. & N.A. & N.A. & N.A. & N.A. \\
\hline Kinshasa & 3,859 & 3,239 & 1,630 & 9,203 & 5,736 \\
\hline Maniema & 7,065 & 5,435 & 3,957 & 4,946 & 3,462 \\
\hline North Kivu (2010) & 6,924 & 6,034 & 3,626 & N.A. & N.A. \\
\hline Orientale & 15,193 & 13,989 & 3,804 & 6,565 & 3,152 \\
\hline South Kivu & N.A. & N.A. & N.A. & N.A. & N.A. \\
\hline
\end{tabular}

Source: Compiled from Mpararo (2011). In 2009, Congo's average monthly per capita income was about U.S.\$25. 
self-serving bias results from the lack of transfer of authority or personnel from the central government to the provinces, which prevents provincial administrations from carrying out service delivery in the sectors constitutionally under their remit. For example Nzweve and Mudinga (2014) show that in North Kivu the provincial government was unable to enact an agrarian reform for reasons that included confusion over the distribution of roles between the national and provincial governments. Most provinces elaborate strategic plans in several areas, but their rates of implementation appear consistently low.

A second reason for the frequent lack of effective provincial governance lies in the high level of political dysfunction of provincial authorities and in their preoccupation with procedural and power disputes. Polarization, paralysis, and sabotage are common in many provinces, and many have had numerous no-confidence votes and changes of governers: in Bandundu, two votes of no confidence and three governors since 2007; in Bas-Congo, two governors; in Equateur, three no-confidence motions and four governors; in Kasai-Occidental (whose provincial assembly is known for its tumultuous, conflict-filled history and where deputies even once exchanged fire during a plenary session), one no-confidence vote and three governors; in Kinshasa, three no-confidence votes; in Maniema, three no-confidence votes and three governors; in Orientale, four no-confidence votes and three governors; in North Kivu, two no-confidence votes; and in South Kivu, at least three no-confidence votes and three governors. In most cases, instability derived from mutual accusations of fraud and corruption and from attempts by provincial assemblies to raise their own salaries by threatening governors with no-confidence motions. In contrast, KasaiOriental and Katanga have been stable.

\section{Decentralization's Fallacy}

Dickovick and Riedl (2014) have shown that partial decentralization reform is common across Africa because central regimes either curtail actual decentralization or use it to enhance their own power. As a result, even among Africa's most decentralized and democratic countries, decentralization has produced "limited advancement with respect to enhancing subnational autonomy, downward accountability, and governance capacity" (2014:249). While the evidence in Congo does not contradict these finding, it suggests that decentralization has in fact increased overall state predation. And this increase has come only partly as a result of the actions of the center and more as the result of the decentralized behavior of regional and local elites. It has been less a matter of partial reform-although there is plenty of that-and more a matter of inadequate implementation resulting in fundamental and unsolved contradictions between the expectations of decentralization and the practice of sovereign authority. Features and actors of Congo's political system have captured the reforms and subjugated them to their own, more powerful, logic. We highlight two reasons for this capture. 
The first lies in the misguided nature of decentralization on account of its neglect of parallel power structures, which negated accountability. The second reason is a misdiagnosis of what ailed Congo in the first place.

\section{Misguided Reforms}

In her study of Ugandan decentralization, Gina Lambright (2011) demonstrates how informal relations between local authorities and the center can undermine or foster decentralization. Formal administrative linkages matter, but informal patronage relations matter more. This is the case in Congo, too, where such informal relations have decidedly undermined decentralization.

Congolese rule is intrinsically dual. Formal structures of governance, including decentralized ones, stand in contrast with the manner in which power is actually reproduced or maintained. The informal Congolese political system remains highly centralized around networks that spread down from presidential circles (U.N. 2011). Through these networks, the regime sends its agents across the territory, appointing them to perform tasks related to security and resource extraction.

Maximization of its own security is an essential occupation of the Kabila regime. This goal has been particularly salient in the regime's use of violence when threatened-for example, against Bundu dia Kongo in 2007 and 2008 (Tull 2010), before and during the fraudulent 2011 elections, against the alleged separatists of Kata Katanga in 2013, and against demonstrators in 2015 who opposed making the next elections conditional upon a census. But the goal also influences the routine administration of the country, especially in the proliferation of instruments of information and control, which are evident at the provincial and local levels as well. In our fieldwork, the policing activities of provinces and ETDs-which were both visible and made explicit to us by our interviewees-echoed the "surveillance" role played by local administrators under Mobutu (Callaghy 1984; Schatzberg 1989).

The Kabila regime is also predicated upon the extraction of local resources. Subordinates are appointed to positions of authority with the understanding not only that they will help themselves, but also that they will "pay" for their appointment by channeling resources upward. This practice, which the Congolese call rapportage, then reproduces itself though all levels of the hierarchy. Baaz and Olsson (2011:223) have documented these practices in the police force, where "property violations" are "highly organized with large portions flowing upward in the chain of command." Malukisa (2014) documents the exact payments expected by the hierarchy from different traffic regulation assignments. In Kasai-Occidental, Trésor Kapuku, who was governor until 2012, was entrusted by Evariste Boshab, a core operative of Kabila's network, "with returning large amounts of the provincial budget to him and other senior officials." According to a donor report, "Boshab was also reported to have chosen all of Kapuku's provincial 
ministers in 2006, most of whom would have agreed to return portions of their salaries, budgets, and revenue to Boshab in exchange for their appointments" (Atos 2013).

Security motives and rapportage highlight the dualism of the state. There is a commitment to good governance embodied in the adoption of formal rules and practices, including decentralization. But there is a less visible structure of power radiating from presidential circles that is focused on security and extraction and that depends on placing and maintaining loyal allies or clients in positions of local control and resource extraction. Provincial elections and autonomy have thus undermined this latter system much less than the proponents of decentralization hoped for. While the regime curtailed decentralization as early as 2007 with the flawed elections of governors, the necessity for decentralized elites to participate in the informal system of rapportage has further undermined the capacity of decentralization to produce accountability and self-administration. At the same time, the extractive nature of the networks has increased the pressure on governors and their subordinates to plunder their province's resources and populations.

Some provinces have managed, nonetheless, to allocate resources to public investments and to design policy programs. Such variation in the governance quality of provinces may derive in part from their wealth endowments, with Katanga dwarfing all others. They are also likely to proceed from the wealth and subsequent autonomy of their elites. Katanga Governor Moïse Katumbi was a wealthy businessman before coming to power in 2007. He and his administration may have instrumentalized their office less than others because their need for accumulation was more limited. As such, they were also possibly more autonomous from networks of rapportage. Other recently elected independently wealthy governors, such as Alex Kande in Kasai-Occidental and Jean Bamanisa, could have followed in Katumbi's footsteps had their provinces not been disbanded in 2015 .

\section{Misdiagnosed Problems}

A reliance on decentralization to combat personal rule, unaccountability, and predation assumed that Congo's ills resided at the top and that, by spreading power, reforms could neutralize "bad leadership." However, personal rule, unaccountability, and predation are not a matter of central elite behavior alone. They are pervasive features of Congolese political life and result, at least in part, from a widespread understanding of the state as a resource. Decentralization multiplied the tools of statehood and the number of claimants to its benefits, but it did not, on average, wrestle these tools away from abusive leaders to give them to accountable local actors.

The pervasiveness of predation at all levels of Congolese society is well documented. The famous notion of "Article 15," an imaginary constitutional provision, embodied Mobutu's injunction to the Congolese to "fend for yourself" (by "stealing, but not too much at once"), which opened the 
ethical door to generalized exactions. Commenting on the situation in the 1970 s, Schatzberg noted that "extraction, exploitation, and oppression" were widespread and that the Congolese lived in a "society where corruption, dishonesty, and inhumanity have become all too common." All "Zairians in positions of authority," he said, "use their parcels of power to extract what they can from those in contextually inferior positions" (1989:3,6,49), with (imaginary) fines and taxes used as a common tool for this extraction. More recently, Englebert (2009) provides a litany of Congolese state agencies whose existence has been largely co-opted for the purpose of extracting resources from citizens at the local level without equivalent delivery of services. Trefon (2011) paints a picture of a Congo where civil servants are seen as predators by the population and where dysfunctional institutions endure because they feed those that occupy them. Malukisa (2014) illustrates predation on the part of traffic police in Kinshasa, where minibus operators drive with their hand reaching out the window with cash for police, while Cuvelier and Muamba (2013) discuss the predatory behavior of customs officials. Aspirations to decentralization glossed over these structural problems to focus on constraining leadership. Outsiders targeted their demands for institutional accountability, transparency, or responsiveness at incumbents, but these reforms diminished as the outsiders themselves gained access to state authority and as the new incumbents managed to advance their own welfare in many of the decentralized positions. In this way, the enactment of decentralization policies paradoxically reduced the demand for decentralization itself by increasing the number of those with access to the state.

This analysis does not imply Congolese duplicity. What it implies is a misdiagnosis of the mal congolais as a problem of leadership in need of safeguards rather than as a systemic condition. People may desire better governance and yet be unable to extract themselves from participating in relations of predation. Obtaining access to provincial and local power did not automatically produce accountable behavior or checks and balances between local and central authority. It did, however, multiply opportunities for predation, especially after laws conferred upon provinces the right to raise taxes independently of Kinshasa. For sure, Kinshasa was able to place loyalists with no genuine commitment to decentralization in many provincial and local positions, but there is no indication that political affiliation has determined the behavior of decentralized elites.

State predation is a consequence of the pursuit of the state as a resource. This pursuit is in turn a function of the phase of resource accumulation that Congolese elites at all levels of statehood are in. Despite the country's kleptocratic reputation, most Congolese, elites included, were left impoverished by the economic decline that began in the mid-1970s and accelerated from the mid-1990s onward. Few politicians from the Mobutu era appear to have accrued lasting or at least visible wealth, as his system was predicated upon preventing potential contenders from accumulating resources (Young \& Turner 1985; Schatzberg 1989). Moreover, many of the current 
elites, particularly Katangese, were largely excluded from the Mobutist circles and are engaged in a catch-up race. At the local level, particularly in ETDs, poverty is prevalent and extraction of resources through "legal command" (Englebert 2009) can be a survival strategy. Competition among many claimants for relatively few resources-at U.S.\$30 billion, Congo's GDP is equal to the budget of the U.S. state of Indiana-accounts for the predation of local institutions. The fact that as many as 80 percent of the members of provincial assemblies are newcomers to politics (Omasombo 2010) magnifies the need for accumulation and partly explains the selfserving and extractive nature of provincial governance.

In retrospect, one can see that there was a coincidence of perspectives among donors and the Congolese, which gave decentralization the allure of an irresistible force. Focusing on formal institutions and hoping that mechanisms such as elections and transparency requirements would bring reform to the system, donors pushed hard for decentralization and worked with provinces under the assumption that the more local the governance, the better it would function. The Congolese, for their part, focused on the sins of their leaders but perhaps should have been more concerned about the degree to which the pervasiveness of "anti-values," which they lamented, could undermine the substance of reforms.

In the end, the Congolese mode of governance was more of an immovable object than either party had anticipated. Congolese authorities at the national level largely got away with signaling to donors their willingness to decentralize without doing much about it. Focusing on formal reforms, donors may have missed the limited extent to which these changed the actual nature of governance. Moreover, after a few laws were passed, decentralization got stuck in the quagmire of Congolese policy reform and implementation. A number of committees were set up; meetings, workshops, and forums were held; calendars and strategic plans were produced. But there was little incentive to do much more once provincial authorities were created and decentralization was captured.

The last piece of the puzzle is the apparent acquiescence of the local victims of decentralized predation. Decentralization reforms are predicated on the idea that, once given local institutions, local communities can have a voice, exercise control, and demand accountability. Giving these local institutions taxation authority was expected to further reinforce their accountability, as citizen vigilance would increase with their financial contributions. Such a model, however, assumes a degree of information and knowledge that is not empirically validated in Congo, where uncertainty prevails with respect to rules, authority, and the power and duties of institutions (Englebert 2012; Trefon 2013). This uncertainty has many sources, including the sedimentation of past reforms, the multiplicity of institutions tasked with various dimensions of ongoing reforms, the propensity for permanent negotiation of the Congolese political system (Englebert \& Tull 2013), a frequent failure to implement actual laws (which Senator Lunda Bululu imputed to a "culture of non-respect of texts" [Radio Okapi, 
September 13, 2009]), and significant informational asymmetries between different levels of governance and between the rulers and the ruled. In several instances during our fieldwork, for example, we met ETD authorities who were unaware of the legal texts regulating their activities and status. In this environment, those who occupy sovereign positions are largely unfettered in their exercise of authority.

\section{Conclusions and Implications}

Congo's decentralization reforms backfired. Our research shows that, far from promoting accountability, voice, and a governance of proximity, decentralization reforms fostered greater predation, provincial centralization, unaccountable governance, and self-serving provincial elites. We have suggested that the failure of decentralization reforms derived in part from the offsetting effects of informal top-down, security-focused, and extractive governance, and in part from the coincidence of pervasive state instrumentalization and the multiplication of state positions produced by decentralization. The inability of Congolese and donors alike to recognize these features at the onset of reforms led to unrealistic expectations of what decentralization could achieve. Although reforms have seen only partial implementation, we have shown that this outcome is not so much the cause of their capture as its result.

Congo's decentralization problems illustrate the frequent disconnect in Africa between governance reforms and deeper politics. Since the Transition, donors have sought reforms such as elections, budget transparency, bankarization of civil servant salaries, mining sector transparency, and oversight bodies, all of which tie the hands of the central government. Their support for decentralization participates in the same logic, as the rise of alternative and autonomous centers of power promised to constrain Kinshasa. Facing a reluctant central government from the outset, donors helped provincial authorities boost their extractive capacity with multiple and coordinated aid projects. While decentralization might have constrained Kinshasa to a slight extent, it ended up unleashing eleven provincial replications of the central government, as donors overestimated the degree to which provincial actors would represent the interests of local populations. The focus of donors on notions of decentralization disembedded from a more structural understanding of Congolese politics may have made them unwilling accomplices of the failure of reforms.

This finding echoes Matt Andrews's (2013) notion of "complex institutional structures," which suggests that formal institutions are only the tip of the governance iceberg in less developed countries. "Rules of the game," he says-that is, the deeper set of largely informal institutions that condition behavior-remain unaffected by formal reforms (2013:44). In Congo, not unlike in some other African countries, these rules include patronage, rapportage, and the privatization of public office. But while Andrews suggests that formal reforms can produce little more than "change at the margins" 
(2013:111), our findings suggest that they can do worse, actually unleashing the opposite of their initial goal. Congo shows us that formal reforms within an unchanged informal system can worsen overall governance.

In addition, decentralization reforms are predicated on a principalagent model of governance, in which centralized personal rule is seen as stifling popular demand for better governance. While there is little doubt that Congolese would indeed prefer better governance, it is not clear that in practice they can articulate, aggregate, and implement these demands, since most people are largely forced to participate in the existing system to survive or advance their interests. In this case, poor governance is a manifestation of a failure of collective action rather than a principal-agent one, as suggested by David Booth (2012). Decentralization per se neither addresses nor solves this problem. In Congo's case, it provided more opportunities for the problem to manifest itself.

A collective-action understanding of Congo's governance troubles also casts doubt over whether holding provincial and local elections would make any difference. Some might suggest that such elections would be able to bring about greater accountability at all levels. After all, the predation of provinces and ETDs might derive in part from the absence of electionswhich have not taken place in the provinces since 2006 and have never taken place at all for the ETDs. Electoral sanction would amplify local voices and might finally bring about a measure of responsiveness. But as demonstrated in 2007, when several provincial assemblies with opposition majorities elected pro-Kabila governors, the capacity of the regime to control the outcome of elections is considerable. This may be less true at the ETD level where the multitude of positions makes control harder (a possible reason for the regime's resistance to such elections so far). Yet again, such a model implies an independent and informed citizenry unfettered by "complex institutional structures" (Andrews 2013) and capable of articulating policy demands. Congolese deficits in this respect may yet provide elected provincial and local elites with autonomy from their voters.

One cannot rule out the possibility that Congo's predatory decentralization is but a temporary stage toward effective state formation. After all, taxation is the cornerstone of statehood. The many no-confidence motions in the provinces may also be the first sprouts of spreading norms of accountability. Moreover, the coming years may finally witness the transfer of authority to provinces and the beginning of genuine decentralized policies. Kinshasa may be less reluctant about pursuing further decentralization measures if these stand to weaken provincial actors it sees as threats or competitors. In this respect, the increase in the number of provinces to twenty-six in 2015 reflected more a will to undermine some provincial elites, like Moise Katumbi, and prolong Kabila's stay in power, than a commitment to further decentralization. But in some cases this practical motive may end up deepening the commitment to decentralization. Donors too may reap some results from newer programs that are more focused on accountability than capacity, such as the introduction of digitized "expenditure chains" in 
provinces, which are slowly unfolding, and projects to increase citizen involvement, such as the "participatory budget" processes they have launched in some ETDs. The empirical question is whether such formal constraints will eventually reach sufficient critical mass to end up tying the hands of political actors in the informal realm.

\section{Acknowledgments}

Research for this article was funded by a grant from the Earhart Foundation and, in its last phase, by the Africa Initiative at Pomona College. Fieldwork, carried out in installments between 2010 and 2014, included visits to Bas-Congo, Equateur, Kasai-Oriental, Katanga, and Kinshasa provinces. The authors gratefully acknowledge the excellent research assistance of Catriona Craven-Matthews and Manya Janowitz, the generous facilitation provided on the ground by Mailan Chiche, Catherine Dom, Jean Mabi, Balthazar Ngoy, Mamie Patricia Kipanga, Deo Kadia, Jean-Claude Kessous, Rémi Kossouho, Stéphane Muninda, and Agathe Tshipanga, and the careful reading and useful suggestions of Mailan Chiche, Todd Diamond, Catherine Dom, Tom de Herdt, Gina Lambright, Naomi Levi, Stéphanie Perazzone, Theodore Trefon, Denis Tull, three anonymous reviewers, and the editors of the African Studies Review.

\section{References}

Andrews, Matt. 2013. The Limits of Institutional Reform in Development: Changing Rules for Realistic Solutions. Cambridge, U.K.: Cambridge University Press.

Atos. 2013. "Provincial Pilot Study: Kasai Occidental." Kinshasa: Department for International Development, DR Congo.

—. 2014. "Draft Provincial Pilot Study: Equateur." Kinshasa: Department for International Development, DR Congo.

Baaz, Maria E., and Ola Olsson. 2011. "Feeding the Horse: Unofficial Economic Activities within the Police Force in the Democratic Republic of the Congo." African Security 4 (4): 223-41.

Batamba Balembu, Antoine. 2014. "Corruption et décentralisation en RDC." In République Démocratique du Congo: Décentralisation et espaces de pouvoir, edited by Jean Omasombo and Paule Bouvier, 171-91. Tervuren: Musée Royal d'Afrique Centrale.

Booth, David. 2012. Development as a Collective Action Problem: Addressing the Real Challenges of African Governance. London: Overseas Development Institute.

Paul, Bouvier. 2012. La Décentralisation en République Démocratique du Congo de la première à la troisième république, 1960-2011. Tervuren: Musée Royal d'Afrique Centrale.

Bouvier, Paul, and Francesca Bomboko. 2003. Le Dialogue Inter-Congolais: Anatomie d'une négociation à la lisière du chaos. Cahiers Africains 63-64. Paris: L'Harmattan.

Callaghy, Thomas, 1984. The State-Society Struggle: Zaire in Comparative Perspective. New York: Columbia University Press.

Carothers, Thomas, and Diane De Gramont. 2013. Development Aid Confronts Politics: The Almost Revolution. Washington, D.C.: Carnegie Endowment. 
Cour des Comptes. 2013a. "Cahier d'observations de la Cour des Comptes sur la reddition des comptes du budget de la province du Bandundu pour l'exercice 2012." Kinshasa: Cour des Comptes.

—. 2013b. "Rapport général sur le controle de l'exécution de l'édit budgétaire No 013/011 du 04 novembre 2011 en vue de la reddition des comptes du budget de la province du Bas-Congo pour l'exercice 2012." Kinshasa: Cour des Comptes.

- 2013c. "Rapport general sur le controle de l'exécution de l'Edit budgétaire No12/K.OCC/2011 du 02 novembre 2011 en vue de la reddition des comptes du budget de la province du Kasai-Occidental pour l'exercice 2012." Kinshasa: Cour des Comptes.

—. 2013e. "Rapport général sur le controle de l'exécution de l'édit budgétaire No 001/2011 du 30/12/2011 en vue de la reddition des comptes du budget de la ville de Kinshasa pour l'exercice 2012." Kinshasa: Cour des Comptes.

—. 2013f. "Rapport général sur le controle de l'exécution de l'édit budgétaire No 002/011 du 11/11/2011 en vue de la reddition des comptes du budget de la province Orientale pour l'exercice 2012.” Kinshasa: Cour des Comptes.

—. 2013g. "Rapport général sur le controle de l'exécution de l'édit budgétaire No 004/2011 du 11/10/2011 en vue de la reddition des comptes du budget de la province du Sud-Kivu pour l'exercice 2012." Kinshasa: Cour des Comptes.

Cuvelier, Jeroen, and Philémon Muamba Mumbunda. 2013. "Réforme douanière néolibérale, fragilité étatique et pluralisme normatif: le cas du guichet unique à Kasumbalesa.” Politique Africaine 129: 93-112.

De Villers, Gauthier. 2009. République Démocratique du Congo: De la Guerre aux Elections. Cahiers Africains 75. Paris: L'Harmattan.

Dickovick, Tyler. 2014. "Foreign Aid and Decentralization: Limitations on Impact in Autonomy and Responsiveness." Public Administration and Development 34: 194-206.

Dickovick, Tyler, and Rachel B. Riedl. 2014. "African Decentralization in Comparative Perspective." In Decentralization in Africa: The Paradox of State Strength, edited by Tyler Dickovick and James Wunsch, 249-76. Boulder, Colo.: Lynne Rienner.

DRC Ministère du Budget, Secrétariat Général. 2015. Direction de la Préparation et du Suivi du Budget. "Commentaires sur les états du suivi budgétaire à fin décembre 2014.” Kinshasa: DRC Ministère du Budget.

EITI (Extractive Industries Transparency Initiative). 2013. "2011 EITI Report on the Mining Sector." https:/ / eiti.org.

Englebert, Pierre. 2009. Africa: Unity, Sovereignty and Sorrow. Boulder, Colo.: Lynne Rienner.

— 2012. "Incertitude, autonomie et parasitisme: Les entités territoriales décentralisées et l'Etat en République démocratique du Congo.” Politique Africaine 125: $169-88$.

- 2014. "Democratic Republic of Congo: Growth for All? Challenges and Opportunities for a New Economic Future.” Discussion Paper 6/2014. Johannesburg: Brenthurst Foundation.

Englebert, Pierre, and Emmanuel Kasongo. 2014. "Essor provincial et asphyxie locale: Paradoxe des réformes de décentralisation en RD Congo." In Décentralisation et espaces de pouvoir, edited by Jean Omasombo and Paule Bouvier, 51-63. Tervuren: Musée Royal d'Afrique Centrale.

Englebert, Pierre, and Denis Tull. 2013. "Contestation, négociation et résistance: L'Etat congolais au quotidian.” Politique Africaine 129: 5-22. 
European Court of Auditors. 2013. "EU Support for Governance in the Democratic Republic of Congo.” Special Report No 9. Luxemburg: European Union.

Gaynor, Niamh. 2014. "Challenges to Decentralisation in the Democratic Republic of Congo: Beyond the Political Settlement.” Journal of International Development. wileyonlinelibrary.com.

Jibikilay, Makolo. 2014. "Etat des lieux des transferts des compétences aux provinces et aux Entités Territoriales Décentralisées de la République Démocratique du Congo." Paper presented at the Colloque sur la Décentralisation et le Développement Local en RDC, Kinshasa.

Journal Officiel. 2011. "Rapport de la Cour des Comptes sur le contrôle des comptes des provinces pour les exercices 2009 et 2010.” Numéro Spécial, February 15.

Kostner, Markus. [1997]. "Toward Inclusive and Sustainable Development in the Democratic Republic of the Congo."

Kasongo, Emmanuel. 2014. "Décentralisation fiscale et finances publiques." Paper presented at Colloque sur la Décentralisation et le Développement Local en RDC, Kinshasa.

Lambright, Gina. 2011. Decentralization in Uganda: Explaining Success and Failures in Local Governance. Boulder, Colo.: First Forum Press.

Mpararo, Ernest. 2011. "Les gouverneurs et députés provinciaux vivent dans le luxe alors que la population se trouve dans la pauvreté totale." Press communiqué No. 038/LICOCO/SG/, April 29. Kinshasa: Ligue Congolaise de Lutte contre la Corruption.

Malukisa Nkuku, Albert. 2014. "Régulation du trafic et redevabilités multiples de la police de circulation routière dans la ville de Kinshasa: Les amendes de contraventions routières comme objets de négociation." Antwerp: Institute of Development Policy and Management (IOB), University of Antwerp.

Ndaywel è Nziem, Isidore. 1998. Histoire générale du Congo. Brussels: De Boeck and Larcier.

Nzweve, Kambale, and Mushagalusa Mudinga. 2014. "Le projet d'une réforme agraire au Nord-Kivu: Les impasses au point de départ." L'Afrique des Grands Lacs: Annuaire 2013-2014: 199-222.

Nzongola-Ntalaja, George. 2002. The Congo from Leopold to Kabila: A People's History. London: Zed.

ODEP (Observatoire de la Dépense Publique). 2013. "Rapport de l'enquête sur l'évaluation participative de la transparence dans la collecte et l'utilisation des taxes pour l'amélioration du marché central de Kinshasa." Kinshasa: ODEP.

Omasombo, Jean. 2010. "Décentralisation au Congo: L'échec?” La Libre Belgique, April 14.

Prunier, Gérard. 2009. Africa's World War: Congo, the Rwandan Genocide, and the Making of a Continental Catastrophe. Oxford: Oxford University Press.

Schatzberg, Michael. 1989. The Dialectics of Oppression in Zaire. Bloomington: Indiana University Press.

Stearns, Jason. 2011. Dancing in the Glory of Monsters: The Collapse of the Congo and the Great War of Africa. New York: Public Affairs.

Trefon, Theodore. 2011. Congo Masquerade: The Political Culture of Aid Inefficiency and Reform Failure, London: Zed.

—. 2013. "Uncertainty and Powerlessness in Congo 2012." Review of African Political Economy 40 (135): 141-51.

Tedika Kodila, Oasis. 2012. "Corruption en République Démocratique du Congo: Tyrannie des nombres.” Congo-Afrique 51 (464): 300-306. 
Tull, Denis. 2010. "Troubled State-Building in the DR Congo: The Challenge from the Margins." Journal of Modern African Studies 48 (4): 643-61.

United Nations. 2011. "Final Report of the Group of Experts on the Democratic Republic of the Congo.” New York: U.N. Security Council.

van de Walle, Nicolas. 2001. African Economies and the Politics of Permanent Crisis, 1979-1999. Cambridge, U.K.: Cambridge University Press.

Vansina, Jan. 1982. "Mwasi's Trials.” Daedalus 111 (2): 49-70.

Williams, Gareth, and Ephrem Ghonda. 2012. "The Political Economy of Public Financial Management in the Democratic Republic of Congo."

World Bank. 2013. "Project Paper on a Proposed Additional Grant in the Amount of SDR 42.3 Million to the Democratic Republic of Congo for a Governance Capacity Enhancement Project." Report No: 76718-ZR. Washington, D.C.: World Bank.

Young, Crawford, and Thomas Turner. 1985. The Rise and Decline of the Zairian State. Madison: University of Wisconsin Press.

\section{Notes}

1. We focus here on the period 2006-14, before the Kabila regime all but suspended decentralization reforms in 2015 when it broke up existing provinces without making adequate provision for the administration of the new ones, and when it appointed "special commissioners" to manage the new provinces in contravention to both the Constitution and the 2008 decentralization laws.

2. Originally scheduled to become 24 by 2009, they were divvied up in 2015 in a process that all but restored Kinshasa's central authority over them.

3. Authors' estimates, based on data from Ministère des Finances, Service de Reddition des Comptes, January 2013, and Ministère du Budget (www.budget. gouv.cd).

4. Authors' estimates, based on data from the Ministère du Budget (www.budget. gouv.cd).

5. See "Réponses du Ministre Provincial de l'Economie, Finance, Commerce et Industrie du Bas-Congo aux questions et préoccupations des honorables députés, ”June 2, 2011. http://josenkuma.unblog.fr.

6. Authors' estimates, based on data from the Ministère du Budget (www.budget. gouv.cd).

7. After subtracting 9\% from 2013 total executed government revenue and U.S. $\$ 10$ billion from GDP.

8. Congo's central government went from scoring $1 \%$ on the Open Budget Index in 2008 to $39 \%$ in 2015 (http://internationalbudget.org).

9. We are grateful to Cour des Comptes Secretary General Joseph Kitambala Ngbeze for sharing these reports with us before formal publication. 